\title{
遊水室内に水車を設置した縦スリット 直立消波工の曝気能に関する研究
}

\author{
森本 真司 1 重松 孝昌 $2 \cdot$ 加藤 健司 3 \\ 脇本 辰郎 $4 \cdot$ 吉岡 真弥 4 \\ 1学生会員 大阪市立大学大学院 工学研究科都市系専攻 \\ （干558-8585 大阪府大阪市住吉区杉本町3-3-138） \\ E-mail:expentory140@gmail.com \\ 2正会員 大阪市立大学大学院 工学研究科都市系専攻 (同上) \\ E-mail:shige @ urban.eng.osaka-cu.ac.jp \\ 3 大阪市立大学大学院教授 工学研究科機械物理系専攻（同上） \\ ${ }^{4}$ 大阪市立大学大学院准教授 工学研究科機械物理系専攻（同上）
}

\begin{abstract}
著者らは，これまでに，縦スリット消波工の遊水室内に水車を設置する波力発電システムを提案してお り，遊水室内に水車を設置することによって幅広い周期帯で消波性能が向上寸ることを明らかにしてきた． 消波メカニズムは波浪エネルギーの散逸によるものであることから，本波力発電システムは設置海域の曝 気能の向上にも有効であることが期待される. 本研究では, 水理実験と既往の海岸構造物による曝気能に 関する既往研究の知見に基づいて, 波力発電システムの曝気能について検討した.
\end{abstract}

Key Words : Aeration, Mass transfer coefficient, Wave-power generation system, Savonius watermills, Vertical-slotted Breakwater

\section{1. はじめに}

内湾に位置する夏期の港湾海域における底層の貧酸素 化は依然として常態化しており，その有効な対策が打ち 出せない状況にある. 静穏性の確保と周辺環境の改善の 両面が求められていると言える.

東日本大震災以降，再生可能エネルギーを用いた発電 の普及が注目されている，周囲を海に囲まれた日本では， 海洋エネルギーの積極的利用に対する期待は大きく, 潮 流や波力を利用した発電システムの研究が数多く実施さ れている1．このような背景の下，著者らは，船舶航行 の安全性や維持管理費などの観点から，既設の港湾構造 物を利用した発電システム2).3を提案している.

本研究で提案している波力発電システムは, 縦スリッ 卜直立消波工の遊水室内に水車を組み込むものである.

図-1は, 縦スリット直立消波工の遊水室内にサボニウス 水車を設置した場合の反射率の実験值を示している． $T_{q}$ は水車に作用させた負荷トルクを表しており， $T_{q}=0$ は トルクを負荷せず水車が自由回転している状態を， $T_{q}=$ のは大きなトルクを負荷して水車が固定している状態を 表している. また，実線は，数多くの実験結果によって

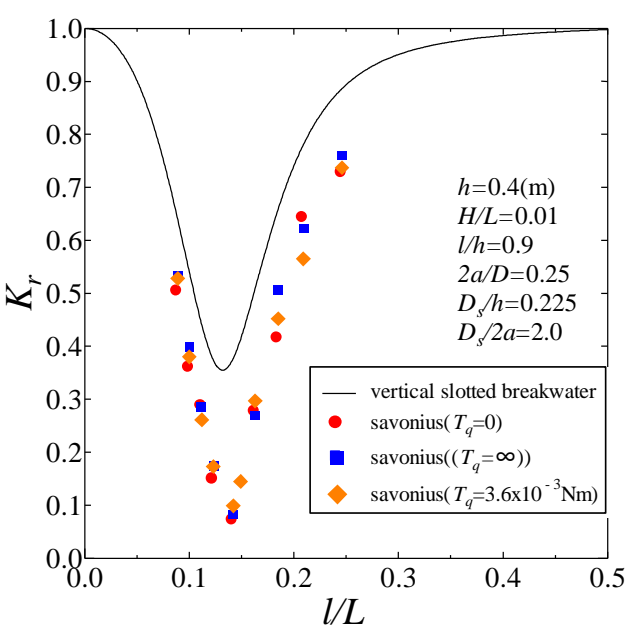

図-1 反射率 $K_{r}$ の実験結果 ${ }^{4)}$

その妥当性が示されている角野りによる縦スリット直立 消波工の反射率 $K_{r}$ の理論值を示している.

$$
K_{r}=\sqrt{1-2 k C_{i} \Gamma_{T}^{2}}
$$

ここに, $k$ は波数, $C_{i}^{\prime}$ および $\Gamma_{\mathrm{T}}$ は以下の式からなる超越 方程式を解くことによって求められる.

$$
\frac{C_{i}^{\prime}}{D}=\frac{4}{9 \pi} \frac{\sinh ^{2} k h+3}{(2 a / D)^{2}(\sinh 2 k h+2 k h)} \Gamma_{T} f \frac{L}{D} \frac{H}{L}
$$




$$
\begin{gathered}
\Gamma_{T}=\sqrt{\frac{A}{A k^{2}\left(C^{2}+C_{i}^{\prime 2}\right)+A k C_{i}^{\prime}-2 k C \sin 2 k l+1}} \\
A=2(1-\cos 2 k l)
\end{gathered}
$$

上式中の $C$ は，慣性抵抗を表す係数であり，角柱列 に対しては次式で求められる.

$$
C=\frac{b}{2}\left(\frac{D}{2 a}-1\right)+\frac{D}{\pi}\left[1-\log \left(4 \frac{2 a}{D}\right)+\frac{1}{3}\left(\frac{2 a}{D}\right)+\frac{281}{180}\left(\frac{2 a}{D}\right)^{4}\right]
$$

ここに，2aはスリット幅， $D$ は柱体中心軸間距離， $l$ は 遊水室幅， $b$ は角柱列の厚み， $H$ は波高， $L$ は波長， $h$ は水深を表し， $f$ は 1.5 の值を取る. 図-1より，水車に作 用するトルクの值にかかわらず，水車を遊水室内に設置 した波力発電システムは，水車の回転運動（負荷トルク $T_{q}$ ）に依らず既存の消波工よりも幅広い周期帯で反射率 が低下することがわかる，このことは，反射率の低下は 波エネルギーの逸散によってもたらされることを考慮す れば，本発電システムは縦スリット直立消波工よりも多 くのエネルギー逸散をもたらしていることを意味する.

一方，気相から液相への気体の取り込久能（曝気能） は構造物周辺におけるエネルギー散冕と密接な関係があ ることが，角野らのや細井ら゙によって明らかにされてい る. 寸なわち, 著者らが提案している波力発電システム は, 波浪エネルギーから電力を担保できるだけでなく, 低反射機能による海域の静穏性の確保とともに, 海域の 曝気能の向上に伴う環境改善も期待されることを示唆し ている，そこで，本研究では，既往の縦スリット直立消 波工の曝気能に関寸る知見に基づいて, 波力発電システ ムの曝気能を実験によって評価することを目的とした.

\section{2. 曝気能の評価式}

Streeter・Phelps ${ }^{8}$ に代表的されるように，水中における 酸素の収支に関する研究は古くから行われている.

Streeter・Phelpsによると, 酸素収支は以下の式で表され る.

$$
\frac{d C}{d t}=-k_{1} L+k_{2}\left(C_{s}-C\right)
$$

ここに，Cは溶存酸素濃度 $(\mathrm{mg} / \mathrm{L}), k_{1}$ は脱酸素係数 $(1 / \mathrm{s})$, $L$ はBOD濃度 $(\mathrm{mg} / \mathrm{L}), k_{2}$ は再曝気係数 $(1 / \mathrm{s}), C_{s}$ は飽和溶 存酸素濃度である. 上式の右辺第1項は, 生物などによ る酸素消費を表す項であるため，本研究ではこれを無視 する. さらに, 式(1)中のCを初期溶存酸素濃度 $C_{0}$ と $C_{s}$ で 無次元化した $C^{*}\left(=\left(C-C_{0}\right) /\left(C_{s}-C_{0}\right)\right)$ を用いて $k_{2}$ について書 き直すと

$$
k_{2}=\frac{-\ln \left(1-C^{*}\right)}{t}
$$

となり，Cの時間変化を求めることによって再曝気係数 $k_{2}$ の值を決定することができる， $k_{2}$ は，温度の影響を受 けるため, 以下の式を用いて水温 $20^{\circ} \mathrm{C}$ 值に補正した.

$$
k_{2(20)}=\frac{k_{2}}{\theta^{T_{w}-20}}
$$

ここに， $k_{2}$ は水温 $T_{w}{ }^{\circ} \mathrm{C}$ での再曝気係数， $k_{2(20)}$ は水温

$20^{\circ} \mathrm{C}$ での再曝気係数, $\theta$ は温度補正係数であり, ここで は $\theta=1.024$ 用いた. 以下に示す $k_{2}$ は, 水温 $20^{\circ} \mathrm{C}$ 值に 補正したものである.

一般的に, 曝気能の評価は, 再曝気係数 $k_{2}$ で評価され る.しかし， $k_{2}$ は，一定の曝気能を有する構造物であっ ても水槽の規模が異なれば值が異なるという問題が生じ る. そのため, 角野らけは, 構造物の曝気能を評価する ためには，曝気容積を限定することで求められる物質移 動係数 $K_{L}$ によって評価すべきであると提案している. また，曝気容積を限定せずに求められた $k_{2}$ は，造波板な どの影響も加わっているなどの指摘もある. 本研究も角 野ら》に倣い, 水理実験を通して $K_{L}$ を求めて, 遊水室内 に水車を設置した場合の曝気能を評価することする， $K_{L}$ と $k_{2}$ の関係は以下のようである.

$$
K_{L}=k_{2} \frac{V}{A}
$$

ここに, $V$ は曝気容積，Aは曝気面積である.

\section{3. 実験概要}

実験は，図-2に示すような長さ $20 \mathrm{~m} ，$ 幅 $0.5 \mathrm{~m}$ ，高さ $0.6 \mathrm{~m}$ の二次元造波水槽を用い, 水深 $h$ を $0.4 \mathrm{~m}$ と一定とし て行った，造波板から約 $14 \mathrm{~m}$ 離れた位置に，不透過壁 と角柱列から成る縦スリット直立消波工の模型(図-3参 照)を設置した，消波工の開口率 $2 a / D$ は 0.25 , 遊水室幅 $l$ は0.275m, 角柱列の厚みbは $0.04 \mathrm{~m}$ した. サボニウス水 車は，スリットに可能な限り近づけて設置し，その径 $D_{s}$ は0.072m, 高さ $H_{s}$ は $0.32 \mathrm{~m}$ とした. 入・反射分離推定法" を用いて入射波高 $H$ および反射率 $K_{r}$ を求めるために, 消波工模型から沖側に $3.5 \mathrm{~m}$ 離れた位置に容量式波高計

（CHT6-100：（株）KENEK製）を2本設置した。これら の值は，波の損失エネルギーを算出するために用いる. 角野らのの実験結果 $(h=0.3 \mathrm{~m})$ によると, 縦スリット直立消 波工による移流拡散は, 数分で不透過壁から $3 〜 4 \mathrm{~m} の$ 領 域に及び，その領域内は，常に濃度が一定であることが 明らかになっている. 本実験も彼らの実験手法に倣い, 遊水室内にウラニン溶液を瞬時に注入したところ, 同様 の結果が得られた。これらを踏まえて，不透過壁から $3.1 \mathrm{~m}$ 離れた位置を厚さ0.02 $\mathrm{mm}$ のビニール膜で区切り, 曝 気容積 $V$ を限定した. ビニール膜は物質移動は許さな 


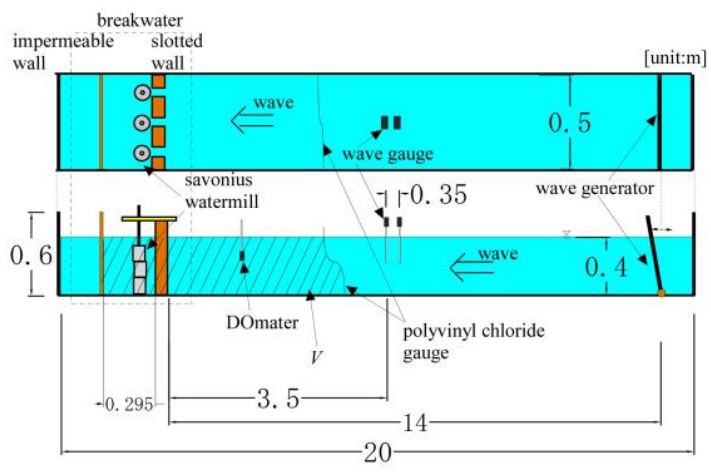

図-2 実験概要

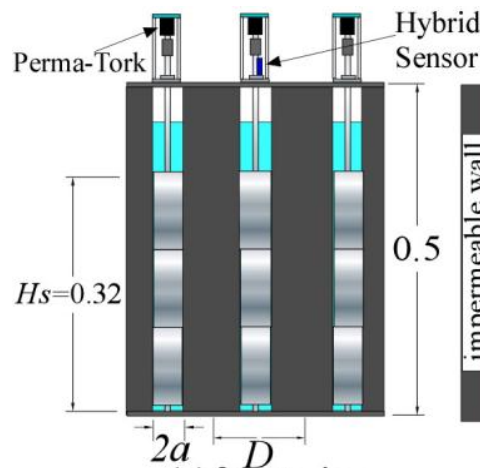

(a)front view

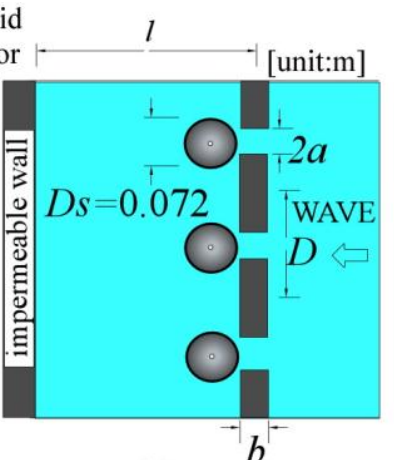

(b)top view
図-3 消波工模型

い材質のものを使用し，波動の伝達にほとんど影響を与 えないように設置した，曝気容積内において，不透過壁 から $1.5 \mathrm{~m}$ 沖の水深 $0.2 \mathrm{~m}$ の位置に蛍光式DO計 (HQ40d：

（株） $\mathrm{HACH}$ 社製）を1本設置し，溶存酸素濃度と水温 を計測した．DO計のサンプリング間隔は30秒で，造波 開始後, 約3時間計測した. 実験に先立って, 亜硫酸ナ トリウムと触媒として塩化コバルトを用い，曝気容積内 をDO濃度を $0.3 \mathrm{mg} / \mathrm{L}$ 以下にし, 貧酸素状態としてから実 験を開始した．水車の回転運動が曝気能に及ぼす影響を 検討するために, 水車は, 無負荷状態 $\left(T_{q}=0 \mathrm{Nm}\right)$ と負荷 を課して固定した状態 $\left(T_{q}=\infty \mathrm{Nm}\right)$ ，および，トルク制 御装置（HC01：日本創販社製）を用いて水車軸に任意 の負荷トルク $T_{q}$ を与えた状態で実験を行った.

\section{4. 実験結果}

\section{(1) 無次元溶存酸素濃度 $C^{*}$ と再曝気係数 $k_{2}$ の実験結果}

遊水室内に水車を無負荷状態で設置し，T=1.2s, $H / L=$ 0.014 0.019の規則波を作用させたときの，無次元溶存 酸素濃度の時間変化，および， $-\ln (1-C$ ”)の時間変化の一 例を図-4 および図-5に示す，図-4より，時間経過と共に 酸素濃度が上昇していくことがわかる，また，図-5には，

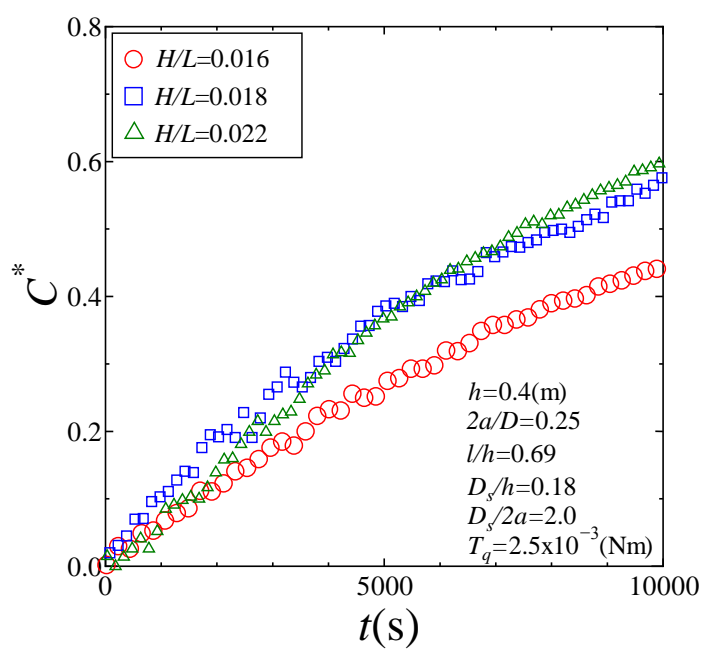

図-4 $C^{*}$ の時間変化 $(T=1.2 \mathrm{~s})$

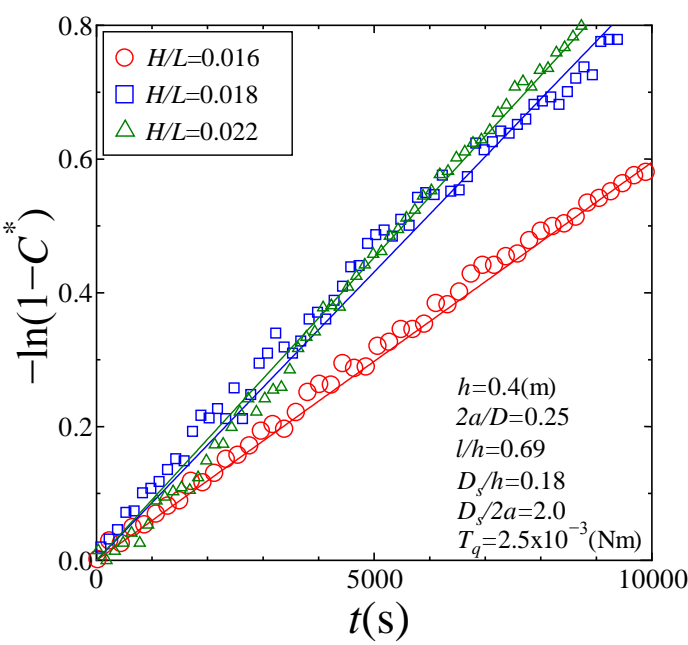

図-5 $-\ln \left(1-C^{*}\right)$ の時間変化 $(T=1.2 \mathrm{~s})$

波浪条件ごとに-ln (1-C") と $t$ が異なる勾配の直線で近似 できることが示されている．この直線の傾きが，式(7) 中における $k_{2}$ の值に相当する. このようにして $k_{2}$ の值 を求めた後，式(9)を用いて $K_{L}$ の值を算出する.

\section{(2) 水車設置時の物質移動係数 $K_{L}$ の実験結果}

水車設置時の $k_{2}$ および $K_{L}$ の実験結果を表-1に示寸. $K_{L}$ の算出方法にあたっては, 角野ら行に倣って, 曝気容 積 $V$ は不透過壁とビニール膜で仕切られた領域の体積 $\left(V=1.24 \mathrm{~m}^{3}\right)$, 曝気面積 $A$ は水槽横断方向のスリット部の 水表面積 $\left(=A \doteqdot 2 a / D \times B \times b=0.01 \mathrm{~m}^{2}\right)$ とした. ここに, $B$ は水槽幅である. 水車は水中に設置しているため, 水車 が曝気に及ぼす影響は無視した。

図-6は，本実験による $K_{L}$ の計測結果を示したもので ある．横軸は，波の損失エネルギー $E_{l}$ を式(10)を用いて 算出し, それを静水時のエネルギー $E_{s}\left(=\rho g h^{2} / 2\right)$ で除した ものである.

$$
E_{l}=\frac{\rho g H^{2}}{8}\left(1-K_{r}^{2}\right)
$$


表-1 実験結果

\begin{tabular}{c|c|c|c|c|c|c|c}
\hline 水車の回転状況 & $T(\mathrm{sec})$ & $H(\mathrm{~m})$ & $H / L$ & $K_{r}$ & $T_{w}\left({ }^{\circ} \mathrm{C}\right)$ & $k_{2}$ & $K_{L}$ \\
\hline & 1.00 & 0.018 & 0.012 & 0.39 & 27.0 & $3.05 \times 10^{4}$ & $3.78 \times 10^{-3}$ \\
& 1.20 & 0.031 & 0.016 & 0.13 & 27.4 & $4.38 \times 10^{-5}$ & $5.43 \times 10^{-3}$ \\
無負荷 & 1.20 & 0.035 & 0.018 & 0.07 & 27.9 & $5.22 \times 10^{-5}$ & $6.48 \times 10^{-3}$ \\
$\left(T_{q}=0 \mathrm{Nm}\right)$ & 1.20 & 0.040 & 0.020 & 0.04 & 20.8 & $7.11 \times 10^{4}$ & $8.82 \times 10^{-3}$ \\
& 1.50 & 0.027 & 0.010 & 0.34 & 25.5 & $3.02 \times 10^{4}$ & $3.74 \times 10^{-3}$ \\
\hline & 1.00 & 0.015 & 0.010 & 0.57 & 27.6 & $3.58 \times 10^{-5}$ & $4.92 \times 10^{-3}$ \\
& 1.20 & 0.027 & 0.014 & 0.24 & 25.1 & $1.96 \times 10^{-5}$ & $2.70 \times 10^{-3}$ \\
固定 & 1.20 & 0.033 & 0.017 & 0.12 & 27.0 & $6.89 \times 10^{-5}$ & $9.47 \times 10^{-3}$ \\
$\left(T_{q}=\infty \mathrm{Nm}\right)$ & 1.40 & 0.035 & 0.015 & 0.21 & 25.0 & $5.48 \times 10^{-5}$ & $6.80 \times 10^{-3}$ \\
& 1.40 & 0.046 & 0.019 & 0.17 & 25.0 & $8.22 \times 10^{-5}$ & $1.02 \times 10^{-2}$ \\
& 1.50 & 0.031 & 0.012 & 0.31 & 27.5 & $4.47 \times 10^{-5}$ & $5.54 \times 10^{-3}$ \\
\hline & 1.20 & 0.032 & 0.016 & 0.14 & 26.6 & $4.93 \times 10^{-5}$ & $6.12 \times 10^{-3}$ \\
& 1.20 & 0.035 & 0.018 & 0.04 & 25.8 & $6.19 \times 10^{-5}$ & $7.67 \times 10^{-3}$ \\
負荷あり & 1.20 & 0.047 & 0.024 & 0.07 & 19.8 & $9.34 \times 10^{-5}$ & $1.16 \times 10^{-2}$ \\
$\left(T_{q}=0 \mathrm{Nm}\right)$ & 1.40 & 0.030 & 0.013 & 0.18 & 27.1 & $4.73 \times 10^{-5}$ & $5.87 \times 10^{-3}$ \\
& 1.40 & 0.044 & 0.018 & 0.20 & 24.8 & $6.84 \times 10^{-5}$ & $8.49 \times 10^{-3}$ \\
& 1.50 & 0.029 & 0.011 & 0.30 & 20.3 & $5.19 \times 10^{-5}$ & $6.44 \times 10^{-3}$ \\
& 1.50 & 0.035 & 0.013 & 0.30 & 20.1 & $5.52 \times 10^{-5}$ & $6.84 \times 10^{-3}$ \\
\hline
\end{tabular}

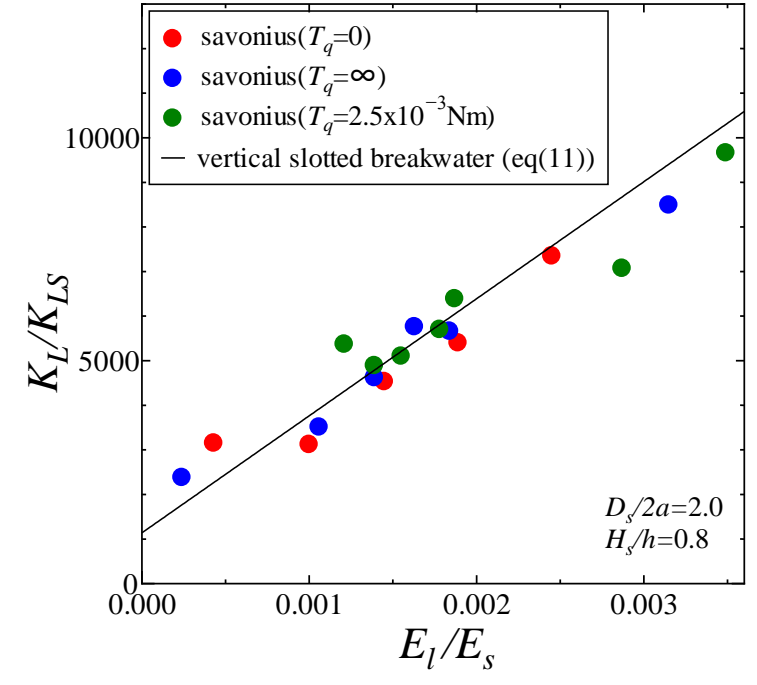

図-6 遊水室内に水車を設置した際の $K_{L}$

一方，縦軸は，物質移動係数 $K_{L}$ を静水状態におけるそ れ $K_{L s}$ で除している. ここで， $K_{L s}$ の值は，角野らのを参 考に $0.12 \times 10^{-5} \mathrm{~m} / \mathrm{s}$ とした. また, 角野りらは, 海岸構造物 の正味の曝気能を評価するために，正弦波の水面変動に 起因する物質移動係数 $K_{L w}$ の影響を除いた物質移動係数 $K_{L}^{\prime}\left(=K_{L}-K_{L w}\right)$ で評価しているが, $K_{L w}$ は $K_{L}$ に対して非 常に小さい值であることから，本研究では無視した．図 -6より，遊水室内に水車を設置した場合の $K_{L} / K_{L s}$ の值は， $E_{l} / E_{s}$ の1次関数で表すことができることがわかる. 図中 の直線は，角野らのが実験によって得られた縦スリット 直立消波工の $K_{L}$ から求めた $K_{L}$ と $E_{l}$ の関係式(11)である.

$$
K_{L} / K_{L s}=2.6 \times 10^{6} E_{l} / E_{s}+1.1 \times 10^{3}
$$

図-6中の実験值と式(11)で表される直線との相関は概ね 良好であることから，縦スリット直立消波工にサボニウ ス水車を付加した本波力発電システムの $K_{L}$ は，縦スリ
ツト直立消波工を対象として求められた式(11)によって 推定できることがわかる，また， $K_{L} と E_{l}$ の関係は，水車 への負荷トルクの大小, すなわち, 水車の回転運動には 依存しないことがわかる. 森本ら奋によれば，本波力発 電システムの反射率 $K_{r}$ は, 縦スリット直立消波工の $K_{r}$ よりも小さな值となって反射特性が向上し，その低下量 は水車の回転速度に依存しない (図-1参照)。このことは, 消波に伴う波のエネルギ一損失は水車の回転速度に依存 しないことを意味している．一方，角野らのや細井ら7) によると，構造物の曝気能は波エネルギーの散逸に依存 することを明らかにしている. すなわち, 縦スリット直 立消波工にサボニウス水車を付加することによって反射 性能が向上し，これに伴って曝気能も向上するとともに， 既往の知見を用いて反射率から曝気能を概水評価するこ とが可能であることが明らかになった。

\section{(3) 水車設置時の曝気能の予測式}

角野らのの実験結果によって導かれた縦スリット直立 消波工の $K_{L}$ 直線と遊水室内に水車を設置した際のそれ は，ほぼ同じであることから，水車設置時の曝気能は， 式(11)で予測することができる．波の損失エネルギー $E_{l}$ は，波高 $H$ と反射率 $K_{r}$ で表されるので，水車設置時の $K_{L}$ は $H$ と $K_{r}$ の值を式(11)に代入することによって求める ことができる，現段階では，遊水室内に水車を設置した 際の $K_{r}$ を予測することはできないが，実験を行って $K_{r}$ を 求めれれば， $K_{L} / K_{L S}$ を予測することができる.

図-7は，式(1)より求められる縦スリット直立消波工の $K_{r}$ の理論值を用いて得られる $E_{l}$ を式(11)に代入すること によって推定される縦スリット直立消波工の $K_{L} / K_{L s}$ と， 水車設置時のその実験值とを比較したものである. 図-7 
表-2 実験結果 $(H / L=0.010)$

\begin{tabular}{c|c|c|c|c|c|c|c}
\hline & $T(\mathrm{~s})$ & $H(\mathrm{~m})$ & $H / L$ & $K_{r}$ & $T_{w}\left({ }^{\mathrm{C}} \mathrm{C}\right)$ & $k_{2}$ & $K_{L}$ \\
\hline & 1.00 & 0.014 & 0.010 & 0.61 & 7.9 & $1.49 \times 10^{-5}$ & $1.85 \times 10^{-3}$ \\
縦スリット直立消波工 & 1.20 & 0.019 & 0.010 & 0.43 & 7.2 & $2.46 \times 10^{-5}$ & $3.05 \times 10^{-3}$ \\
& 1.50 & 0.025 & 0.010 & 0.54 & 9.7 & $3.19 \times 10^{-5}$ & $3.96 \times 10^{-3}$ \\
& 1.65 & 0.029 & 0.010 & 0.62 & 10.7 & $2.72 \times 10^{-4}$ & $3.37 \times 10^{-3}$ \\
\hline \multirow{3}{*}{ 遊水室内に水車を設置 } & 1.00 & 0.015 & 0.010 & 0.49 & 9.4 & $1.72 \times 10^{-5}$ & $2.14 \times 10^{-3}$ \\
& 1.20 & 0.020 & 0.010 & 0.28 & 9.8 & $2.28 \times 10^{-5}$ & $2.83 \times 10^{-3}$ \\
& 1.50 & 0.026 & 0.010 & 0.39 & 7.7 & $3.74 \times 10^{-5}$ & $4.63 \times 10^{-3}$ \\
& 1.65 & 0.030 & 0.010 & 0.48 & 9.1 & $2.98 \times 10^{-5}$ & $3.69 \times 10^{-3}$ \\
\hline
\end{tabular}

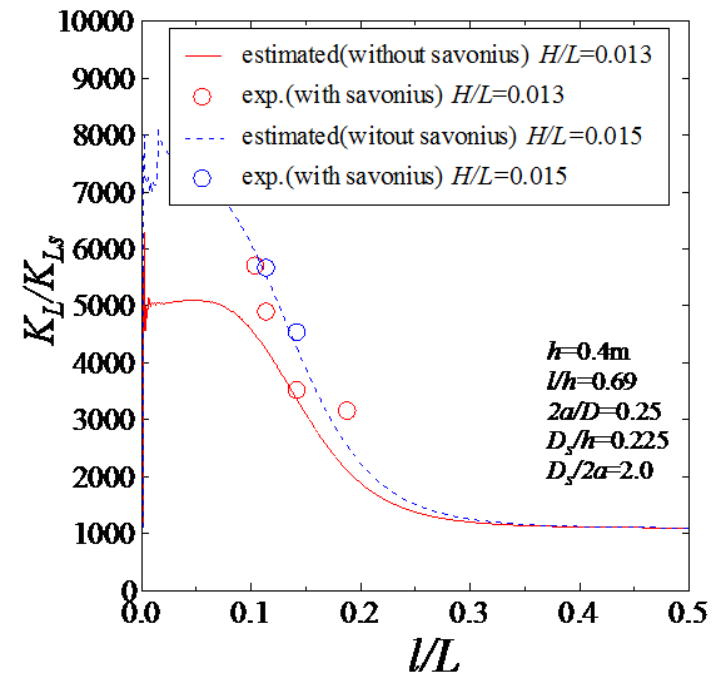

図-7 縦スリット直立消波工の $K_{L} / K_{L S}$ の予測值と 水車設置時の $K_{L} / K_{L S}$ の実験值

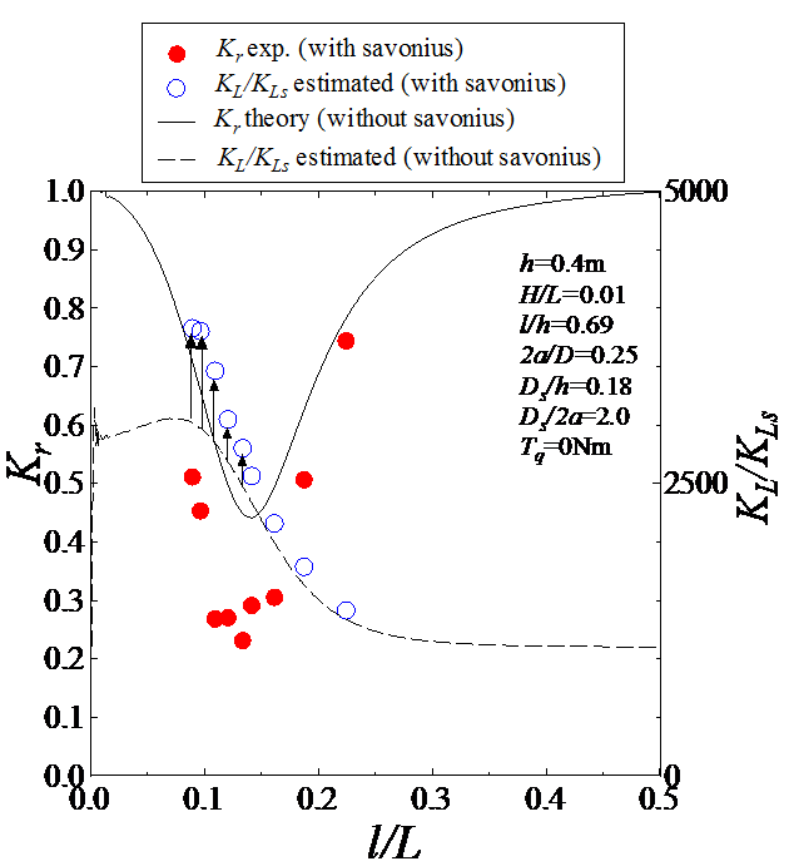

図-8 水車設置時の $K_{r}$ と $K_{L} / K_{L s}$ の予測值

より, $H / L=0.015 の$ 場合には縦スリット直立消波工の $K_{L} / K_{L S}$ の推定值と水車を設置した場合の $K_{L} / K_{L S}$ の実験值
とはほぼ一致しているが，実験值 $H / L=0.013 の$ 場合には， 縦スリット直立消波工の $K_{L} / K_{L S}$ の推定值よりも実験值 の方がやや大きな值を取ることがわかる，これは，H/L $=0.013$ の場合には両者の反射率に大きな差があるために エネルギ一損失量 $E_{l}$ が有意に増加するものの, $H / L=$ 0.015 の場合には両反射率に大きな差違がないために $K_{L} /$ $K_{L S}$ の推定結果に影響を及ぼすほどのエネルギ一損失量 の増加がないことを示している.

図-8は，水車設置時の $K_{r}$ を実験によって求め， $K_{r}$ の実 験值から式(11)によって $K_{L}$ を推定した結果を示したもの である. 図中には，縦スリット直立消波工の $K_{r}$ の理論解 と $K_{L} / K_{L S}$ の推定值も示している. 前述のように, 水車を 設置した場合の反射率 $K_{r}$ は水車を設置しない場合の $K_{r}$ よ りも低下している.このことは，水車を設置することに よってエネルギ一損失量 $E_{l}$ が増加することを意味し，そ の結果として水車設置時の $K_{L}$ は水車を設置しない場合 よりも大きな值を取ると推測される.このような推測及 び本推定手法の妥当性を検証するために, 縦スリット直 立消波工の反射率 $K_{r}$ と物質移動係数 $K_{L}$ を実験によって求 めた後，その遊水室にサボニウス水車を設置した場合の それらを実験によって求めた結果(表-2)を図-9に示す. 作用波の波形勾配はH/L=0.01で，縦スリット直立消波工 の $K_{r}$ の理論解と $K_{L} / K_{L S}$ の推定值も示している. 同図より, 縦スリット直立消波工の $K_{r}$ は実験值と理論值の整合性は 極めて良好であることがわかる，また，水車を設置した 際の $K_{r}$ は，設置しない場合よりも約10～20\%小さい值を とることがわかる. 一方で， $K_{L} / K_{L s}$ は，図-8に示されて いる結果とほぼ同じ傾向を示していることがわかる.す なわち，短周期側 $(0.15<\| L)$ では縦スリット直立消波工 と水車設置時の $K_{L} / K_{L S}$ の值はほとんど変わらないが，長 周期側 $(0.15>/ L)$ では水車設置時の方が大きい值をとる. これらの結果から, 遊水室内に水車を設置すると, 既存 の縦スリット直立消波工が本来有する曝気能に影響を与 えることなく，むしろ長周期側では曝気能が向上し，さ らに，既往の海岸構造物を対象とした物質移動係数と反 射率の関係式から定量的に予測できることがわかった. 


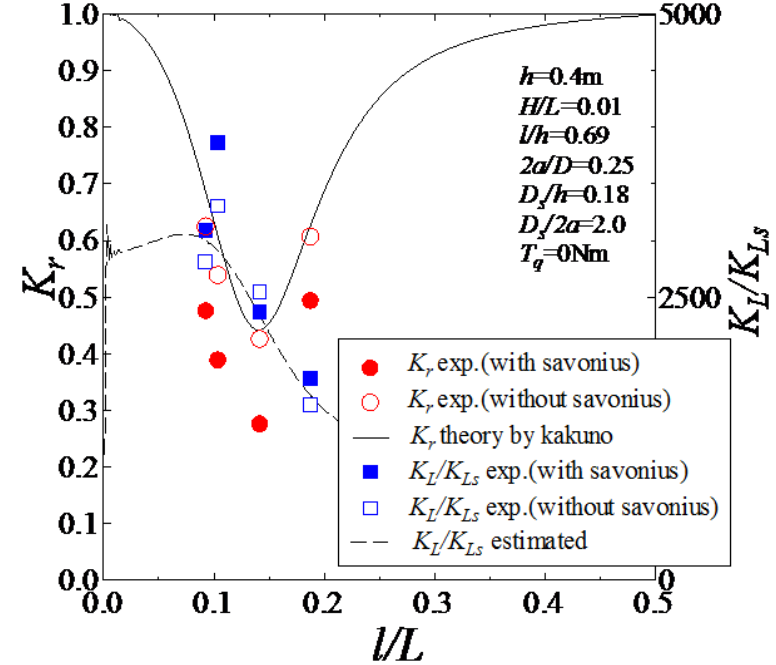

図-9 縦スリット直立消波工の $K_{L} / K_{L s}$ の実験值と 水車設置時の $K_{L} / K_{L S}$ の実験值

\section{5. おわりに}

本研究は，縦スリット直立消波工の遊水室内にサボニ ウス水車を設置することが，曝機能に及ぼす影響を水理 模型実験によって検討した。本研究によって得られた結 論を要約すると以下のようである.

・縦スリット直立消波工の遊水室内に水車を設置した場 合の物質移動係数 $K_{L} / K_{L s}$ と波の損失エネルギー $E_{l} / E_{s}$ に は，既往の縦スリット直立消波工に対するそれらと同 様な線形関係で表されることが明らかになった。

・遊水室内に水車を設置すると，一般的には曝機能は向 上し，長周期波ではそれが顕著である。また，それは， 水車の回転速度には依存しない.

・遊水室内に水車を設置した際の物質移動係数 $K_{L}$ は,
海岸構造物を対象とした既往の推定式を用いて，概ね， 定量的に推定できることが明らかになった.

\section{参考文献}

1) 独立行政法人 新エネルギー・産業技術総合開発 機構編 : NEDO 再生可能エネルギー技術白書第 2 版，第 6 章 84 p， 2014.

2) 重松孝昌, 脇本辰郎, 吉岡真弥, 加藤健司 : 縦スリ ット式直立消波工を利用した波力発電の試み，海岸 工学講演会論文集，第 67 巻, pp.1231-1235， 2011.

3) 脇本辰郎, 吉岡真弥, 重松孝昌, 加藤健司：縦スリ ット式直立消波工を利用した波力発電システムの開 発一水車ならびに屈曲板を利用した発電機構-，実験 力学, Vol.13, No.1, pp.60-66, 2013.

4）森本真司，高田浩太郎，重松孝昌，脇本辰郎，吉岡 真弥・加藤健司 : 遊水室内への水車の設置が消波工 の反射特性に及ぼす影響と獲得動力に関する研究, 海岸工学講演会論文集, 第 70 巻, pp.1296-1300, 2014.

5) 角野昇八 : 鈶直のスリットを有する海岸・海洋構造 物の周辺波動場に関する研究，大阪市立大学学位論 文，171p，1987.

6) 角野昇八，仲田義弘，斉藤満，中谷成智，芳田利 春・小田一紀 : 海岸構造物の曝気能に関する実験的 再考察，海岸工学講演会論文集，第 35 巻, pp.10361040, 1994.

7) 細井由彦，村上仁士，三井宏 : 各種海岸構造物の曝 気効果と再曝気係数の予測式，海岸工学講演会論文 集，第 41 巻, pp.812-816， 1988.

8) Streeter, N. W. and Phelps, E. B. : A study of pollution and natural purification of the Ohio river, Public Health Bulletin 146, U. S. Public Health Service Washington, D. C., 1925.

9) 合田良美，鈴木康成，岸良安治，菊池治 : 不規則波 における入・反射波の分離推定法，港湾技術研究所 資料，No. 248，1976.

\title{
A STUDY ON AERATION CAPACITANCE OF A VERTICAL-SLOTTED BREAKWATER WITH WATERMILLS IN THE CHAMBAR
}

\author{
Shinji MORIMOTO, Takaaki SHIGEMATSU, \\ Kenji KATOH, Tatsuro WAKIMOTO, and Shinya YOSHIOKA
}

\begin{abstract}
Authors have developed a wave power generation system using a vertical slotted breakwater with water mills in the chamber. It has been already shown that the wave absorption function of the wave power generation system is superior than a vertical slotted breakwater without watermills. In this study, reaeration capacitance of the wave power generation system is investigated on the basis of experimental results and previous research knowledge. It is presented that the reaeration capacitance of the wave power generation system can be estimated by experimental formula for a vertical slotted breakwater with wave reflection coefficient. It is presented that the reaeration capacitance of the wave power generation system can be estimated by experimental formula for a vertical slotted breakwater with wave reflection coefficient.
\end{abstract}

